\title{
Satellite analysis of the severe 1987 forest fires in northern China and southeastern Siberia
}

\author{
Donald R. Cahoon Jr.
}

\author{
Atmospheric Sciences Division, NASA Langley Research Center, Hampton, Virginia
}

\section{Brian J. Stocks}

\section{Forest Fire Research, Forestry Canada, Ontario Region, Great Lakes Forestry Centre, Sault Sainte Marie \\ Ontario, Canada}

\section{Joel S. Levine, Wesley R. Cofer III, and Joseph M. Pierson}

\section{Atmospheric Sciences Division, NASA Langley Research Center, Hampton, Virginia}

\begin{abstract}
Meteorological conditions, extremely conducive to fire development and spread in the spring of 1987, resulted in forest fires burning over extremely large areas in the boreal forest zone in northeastern China and the southeastem region of Siberia. The great China fire, one of the largest and most destructive forest fires in recent history, occurred during this period in the Heilongjiang Province of China. Satellite imagery is used to examine the development and areal distribution of 1987 forest fires in this region. Overall trace gas emissions to the atmosphere from these fires are determined using a satellite-derived estimate of area burned in combination with fuel consumption figures and carbon emission ratios for boreal forest fires.
\end{abstract}

\section{Introduction}

Recent concern over the impact of biomass burning on global atmospheric chemistry has resulted in increased research, particularly in the tropics where biomass burning is most extensive [Crutzen et al., 1979; Andreae, 1991].

International projects are addressing this major environmental issue, with initial emphasis on savanna burning in southern Africa and deforestation burning in Brazil. However, large areas of the world's boreal forest zone, which natural fire has shaped over millennia, are also burned annually. Industrial and recreational use of the boreal forest has increased dramatically over the past century, along with forest fire suppression capabilities. However, periodic extreme fire weather events ensure that fires will continue to be common, fulfilling an essential role in boreal forests [Stocks, 1991]. The fires that developed in northeastern China and southeastern Siberia in the spring of 1987 are a recent example of this process.
As a result, this study is expanded to chronicle the development and extent of forest fires in southeastern Siberia during 1987.

National Oceanic and Atmospheric Administration (NOAA) advanced very high resolution radiometer (AVHRR) and Defense Meteorological Satellite Program (DMSP) satellite imagery is used to document fire occurrence and growth and to estimate the areal extent of burning. The general climatology of the region is examined, and trace gas emissions to the atmosphere are derived.

\section{Regional Climatology}

The climate in the extreme northeastern region of China and in southeastern Siberia is continental cold-temperate, with long, cold, dry winters and short, warm, humid summers. The region is dominated by the Asiatic high in the winter, which forms over the Lake Baikal region and blocks the progression of winter storms. The infrequency of winter storm passages produces relatively little precipitation, with most of the region receiving less than $5 \mathrm{~mm}$. As spring approaches and warming begins, the Asiatic high breaks 
This study began as an investigation of the great China fire, which occurred in May 1987 in the Heilongjiang Province of northeastern China, burning in excess of 1.3 million hectares of prime forest and resulting in the loss of over 200 lives and 50,000 homes [Cahoon et al., 1991]. From examination of satellite imagery pertaining to the development of the great China fire, it became apparent that extensive forest fire activity was concurrently under way across the border in Siberia, particularly in the area east of Lake Baikal between the Amur and Lena Rivers. The widespread fire activity was evidence that the meteorological conditions responsible for the rapid growth of the great China fire were not local phenomena, but extended over a large geographical area.

Copyright 1994 by the American Geophysical Union. down and storm passages occur in rapid succession from west to east. These storms (and frontal systems) bring strong winds and little precipitation. At the same time that storm frequency increases, temperature rapidly increases and humidity remains low. This combination of conditions leads to the drying of forest fuels, creating a prime situation for fire development. In the summer months the frequency of storm passages decreases, but the storm intensity increases. The greater amount of precipitation associated with the stronger storms reduces the fire hazard. With the cooling of autumn the behavior of the spring storms is repeated, but the storms lack the intensity and strong winds common in spring. Although smaller fires occasionally occur, they do not create a control problem. By November the

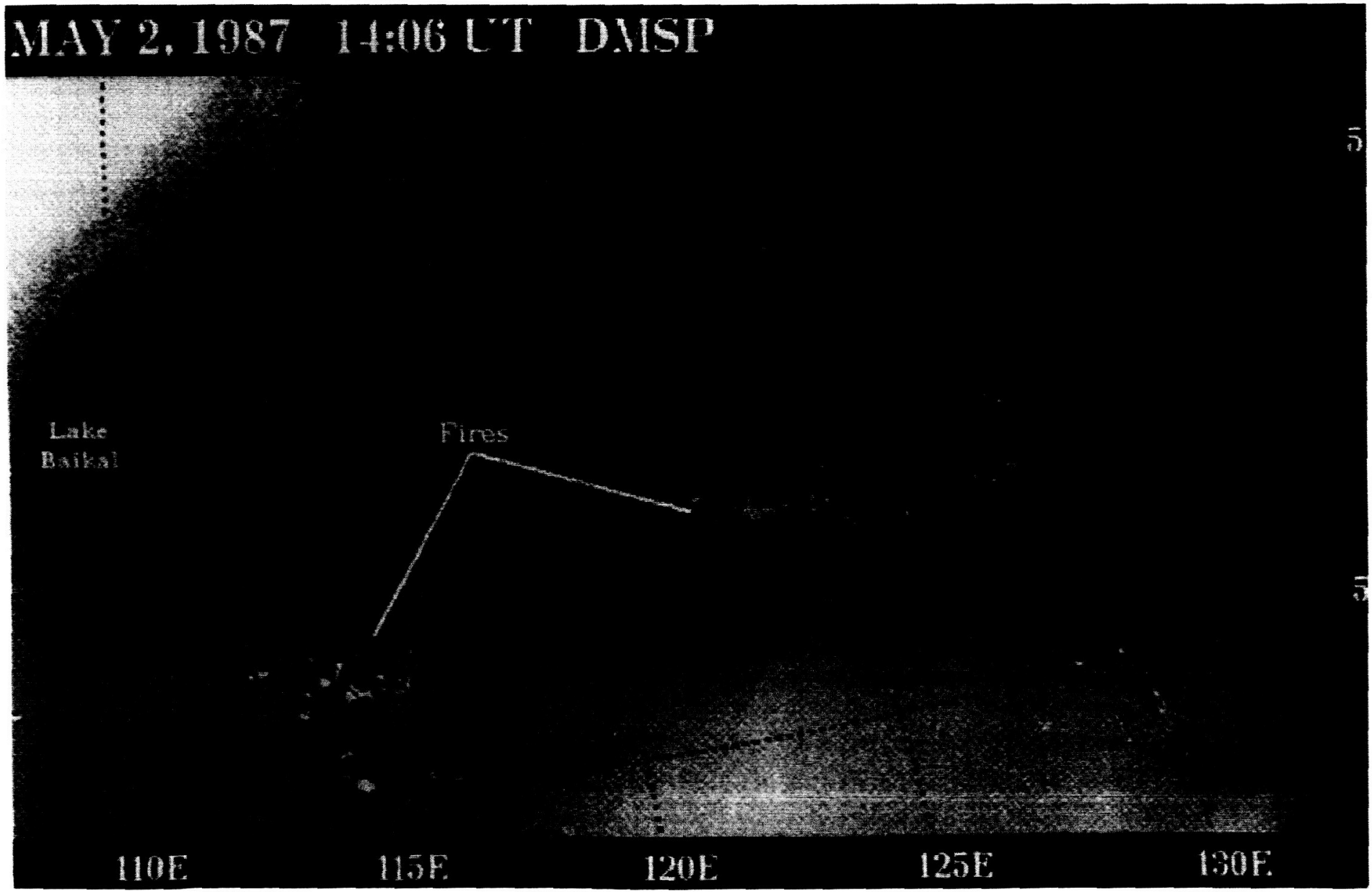


Figure 1. DMSP nighttime image showing fire activity east of Lake Baikal and north of the Amur River. Fires appear as white dots.

Asiatic high has formed, and the dry period begins again. During this annual climatic cycle, forest fires are most frequent and severe in the spring. There are few fires during the summer, and small fire development is common during the autumn [Stocks and Jin, 1988].

Snowfall over the northern China and southeastern Siberia region was typically light during the winter of 1986-1987, and the snow cover had disappeared by early April southeast of Lake Baikal and along the Amur River. Low temperatures and relative humidities prevailed throughout April, with only a light scattering of precipitation. The cumulative result was an extremely dry forest fuel situation in this region by the beginning of May 1987, which combined with increasing temperatures and strong winds to produce uncontrollable forest fires. Stocks and Jin [1988] present a detailed account of the weather conditions prior to and during the great China fire.

\section{Satellite Imagery Analysis of Fire Chronology}

Over 200 NOAA AVHRR images, archived in both the global area coverage (GAC) and local area coverage (LAC) formats [Kidwell, 1991], were examined in this study. Clouds associated with repeated frontal passages made ground observation difficult. In fact, the mean summer cloud Satellite imagery provides a unique perspective cover, from 1971 to 1981 , is at least $60 \%$ over the entire on the growth of the great China fire. Two study region [Warren et al., 1986]. When the opportunity did AVHRR local area coverage (LAC) images arise to observe the ground, it was quickly apparent from the (Plate 2), obtained from Chinese fire research imagery that the great China fire was less extensive than the fires in Siberia. For this analysis, false color composites were produced with AVHRR channels 1, 2, and 4 [Cahoon et al., 1991; Chung and Le, 1984] to distinguish between smoke plumes (orange), snow (yellow), low clouds (yellowishwhite), high clouds (white), water (blue), unburned vegetation (yellow to bluegreen), and burned forest (dark brown to black).

Examination of the AVHRR imagery from late April did not reveal any fire activity, but by May 2, DMSP satellite imagery revealed that forest fires were widespread east of Lake Baikal and (Figure 1). By May 6, these intense fires lifted smoke many kilometers into the atmosphere for long-range transport eastward (Plate 1 (top)). On this date, four forest fires started in the most northern extent of the Heilongiiang Province of China, near the Amur River (Plate 1 (bottom)). One of the four fires was controlled early, despite the severe weather conditions, but the other three grew quickly throughout the day. The remaining fires burned for 3 weeks and eventually coalesced into one large burned region. Even though burning was extensive in Siberia, the phenomenal fire behavior of the great China fire captured international media attention. he three individual fires that eventually coalesced to form he great China fire. The AVHRR 3.7- $\mu \mathrm{m}$ channel, sensitive to high-temperature sources [Scorer, 1987; Matson and Dozier, 1981], was used to accentuate the active fire fronts. rhe fire fronts were clearly visible on the morning of May 7 (Plate 2 (top)) as the fires had burned over an area of 18,000 a. During the afternoon of May 7 , strong winds ahead of an 


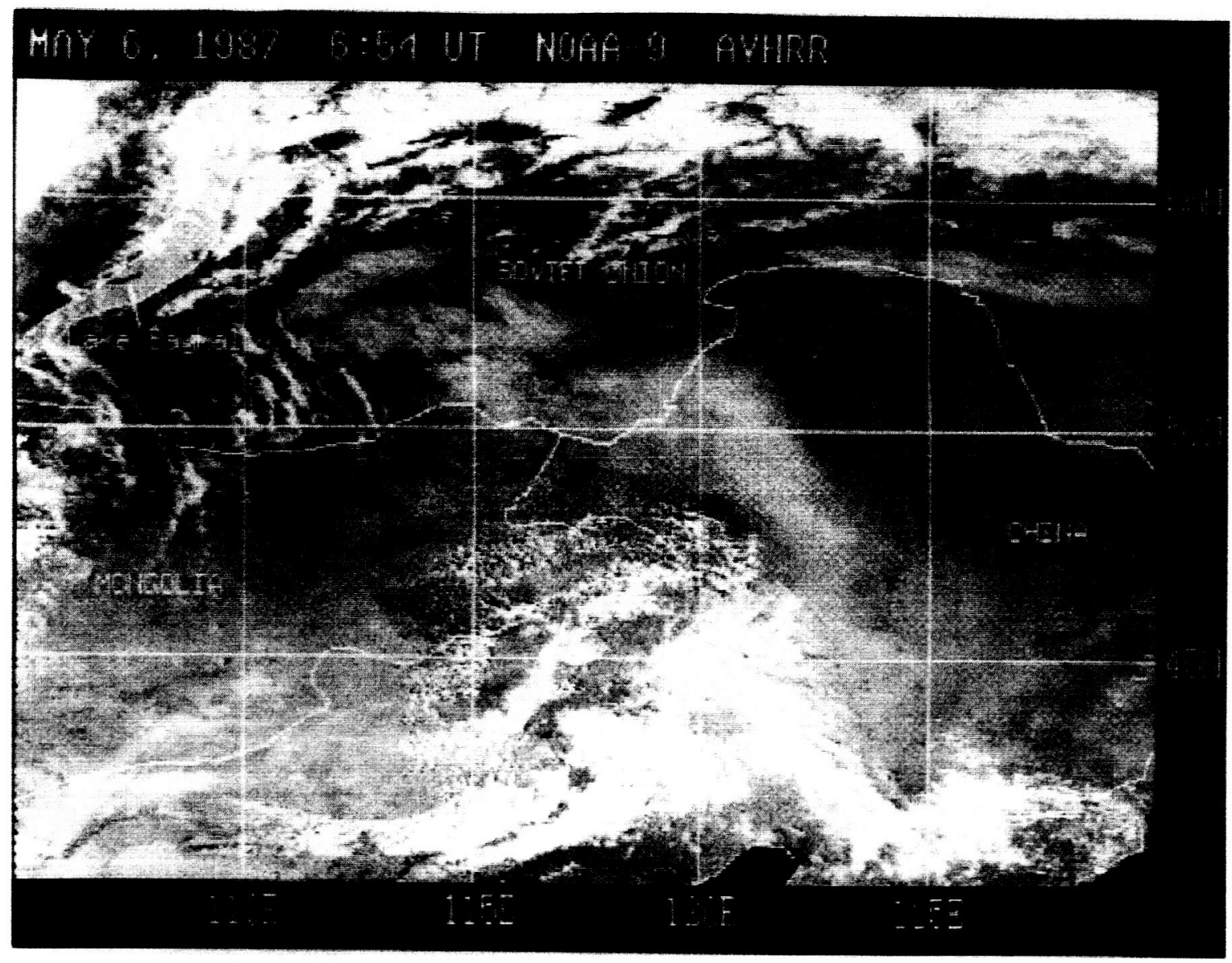




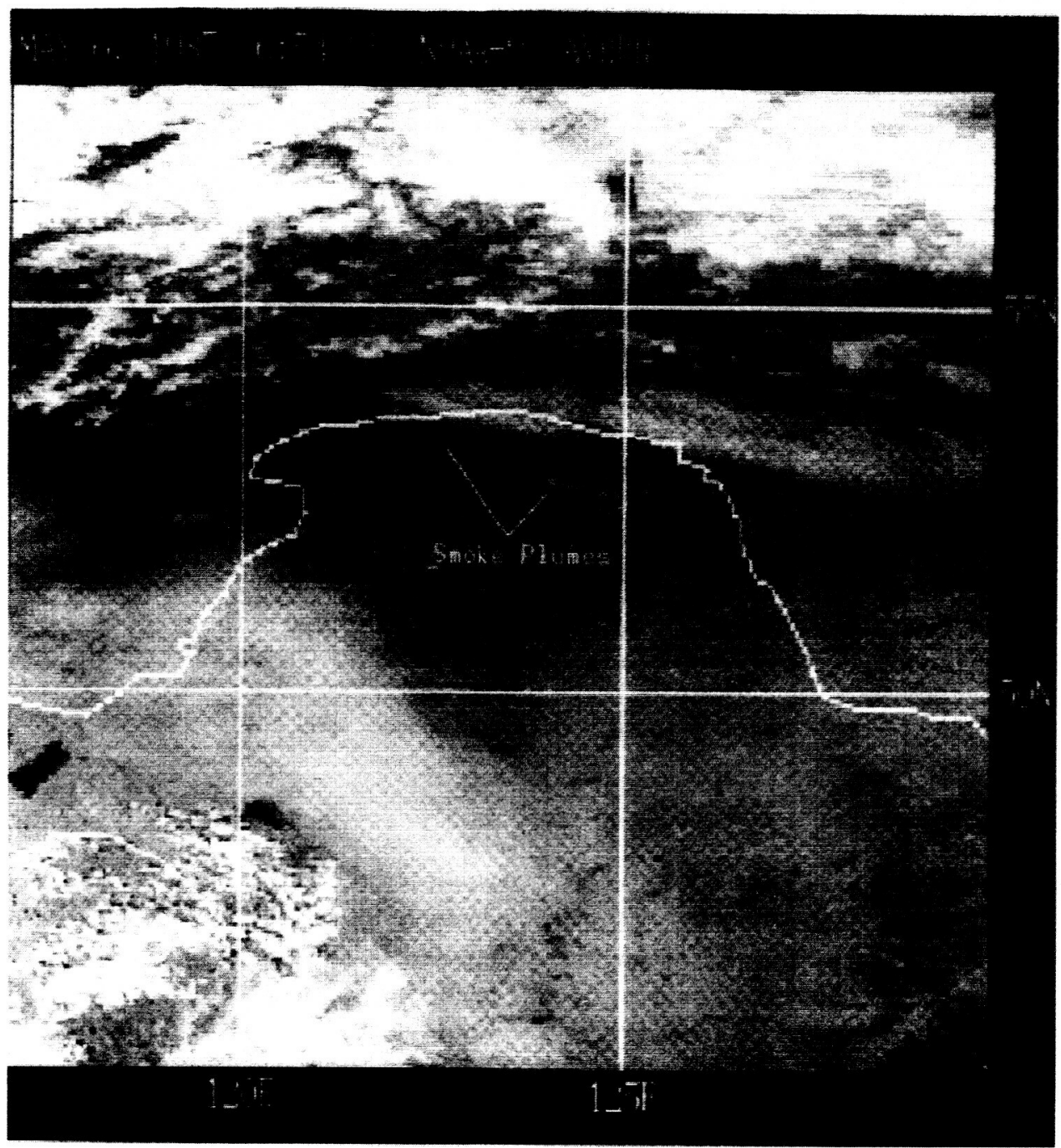

Plate 1. (top) Extensive fire activity between $50^{\circ} \mathrm{N}$ and $55^{\circ} \mathrm{N}$ latitude, east of Lake Baikal and north of the Amur River, is producing an extensive smoke pall that extends toward the Korean peninsula. (bottom) On May 6, two of the three fires that coalesced to form the great China fire have visible plumes. 

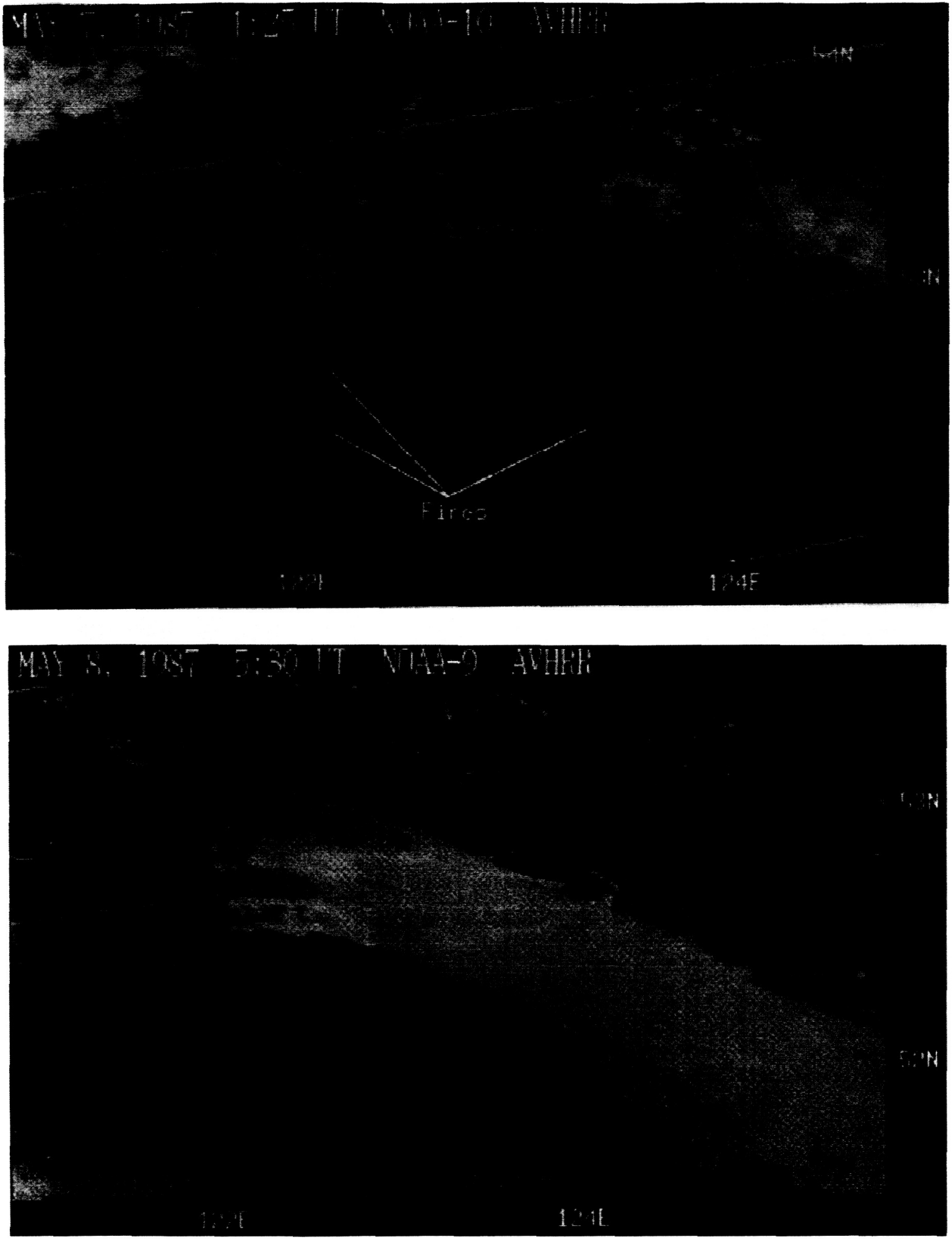

Plate 2. Two AVHRR satellite images showing the rapid intial spread of the great China fire: (top) image from May 7, with the China/Russia border along the Amur River shown through the middle; (bottom) image from May 8, with the border appearing in the upper third. Active fires (red) can be seen on both sides of the border. On May 8 the outer fire perimeter is clearly visible, and smoke is being transported rapidly souteastward by strong winds.

approaching cold front caused the three fires to spread rapidly eastward, each covering a distance of $60-70 \mathrm{~km}$ by late evening, resulting in a total area burned of approximately 350,000 ha. This spectacular growth is evident from the LAC image from the afternoon of May 8 suppressed the fire activity. Smoke palls were visible through breaks in the clouds, but the fires were not as intense. Additionally, fire activity previously not seen was occurring southeast of Lake 8 Baikal (near $52^{\circ} \mathrm{N}, 107^{\circ} \mathrm{E}$ ) and in China near the 
(Plate 2 (bottom)). Despite vigorous suppression activities the great China fire burned for about 3 more weeks, eventually burning in excess of 1.3 million hectares of forested land.

On May 9 the band of active fires from Lake Baikal to China was mostly obscured by clouds associated with a passing frontal system. This frontal system brought some precipitation and lower temperatures and to some degree eastern Mongolian border.

Clear sky imagery for May 16-19 provided an extremely good view of the forest fire situation in northern China and souteastern Siberia. The May 16 image (Plate 3 ) showed a large smoke pall in China and fewer, more scattered, fires in Siberia. Burn scars (dark patches) could be seen on the Russian side (north) of the Amur River. The Matson and Dozier [1981] technique was used to determine the location

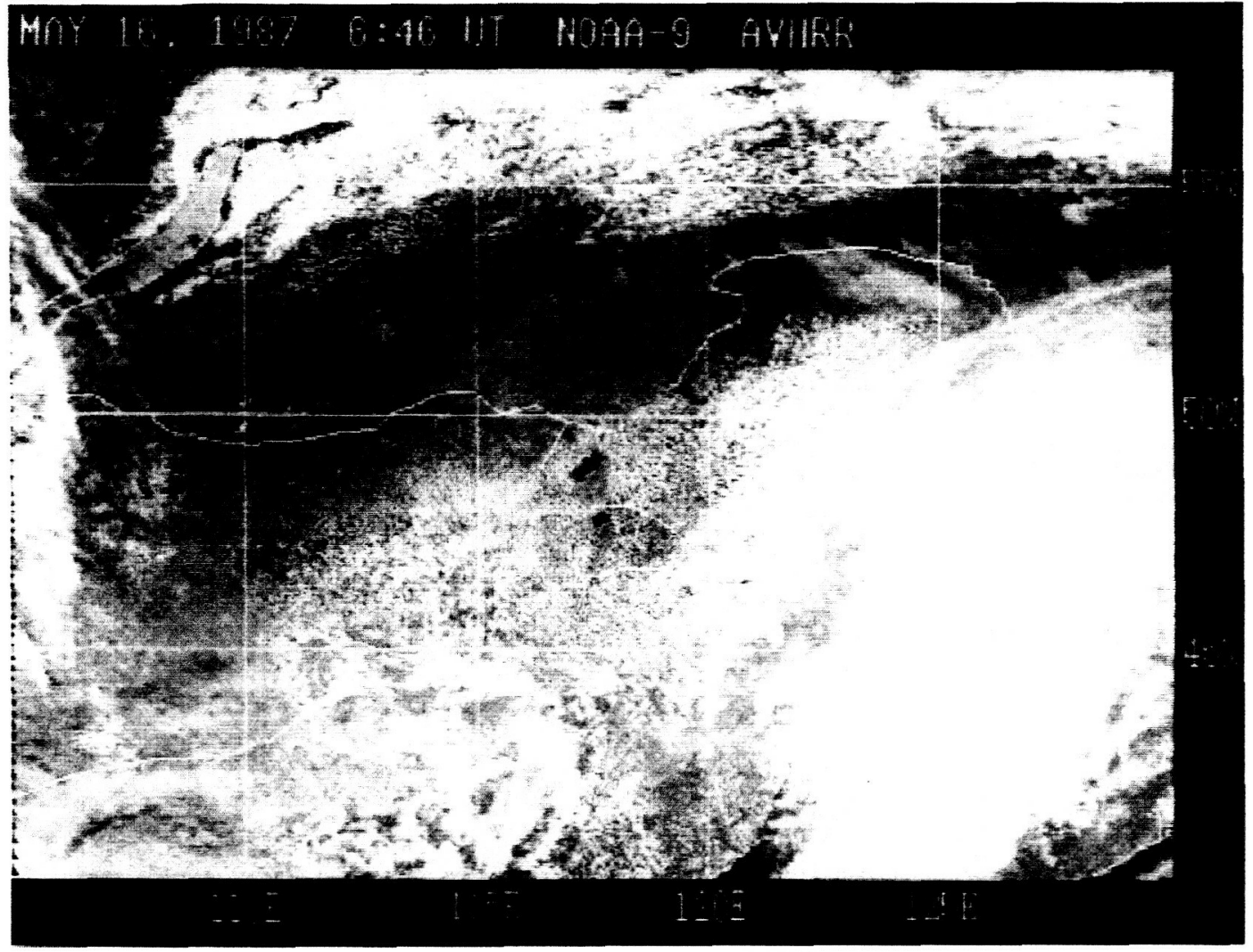

Plate 3. On May 16, 1987, fire activity has diminished to the east of Lake Baikal and north along the Amur River, leaving behind the burn scars (black regions). The great China fire is very active as evident by the smoke pall. 
Satellite Analysis of the Severe 1987 Forest Fires

Page 8 of 18

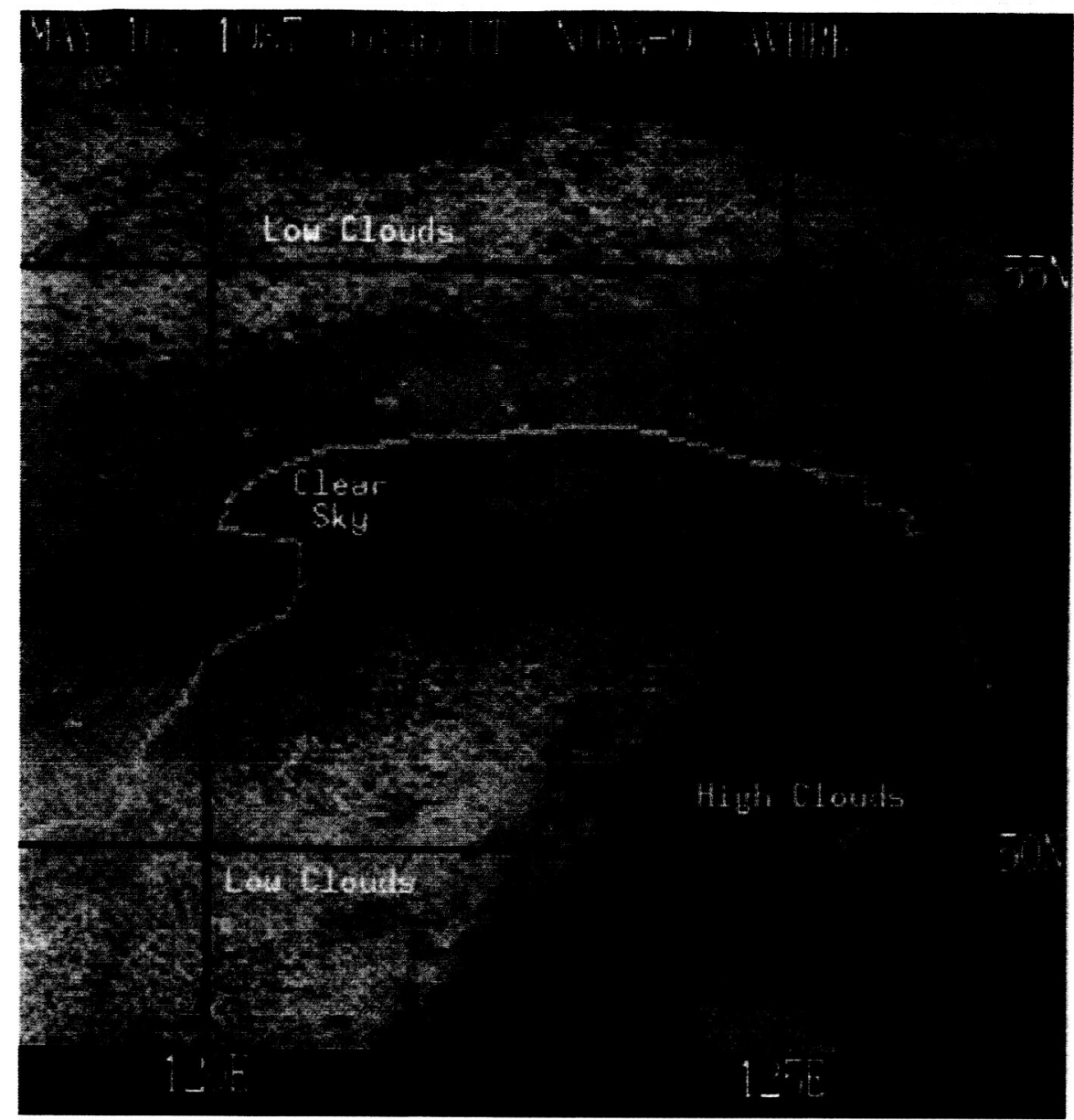

Plate 4. Using the AVHRR 3.7- $\mu \mathrm{m}$ channel, active fire can be detected around the perimeter of the great China fire. The three original fires have almost grown together, but can still be distinguished. 


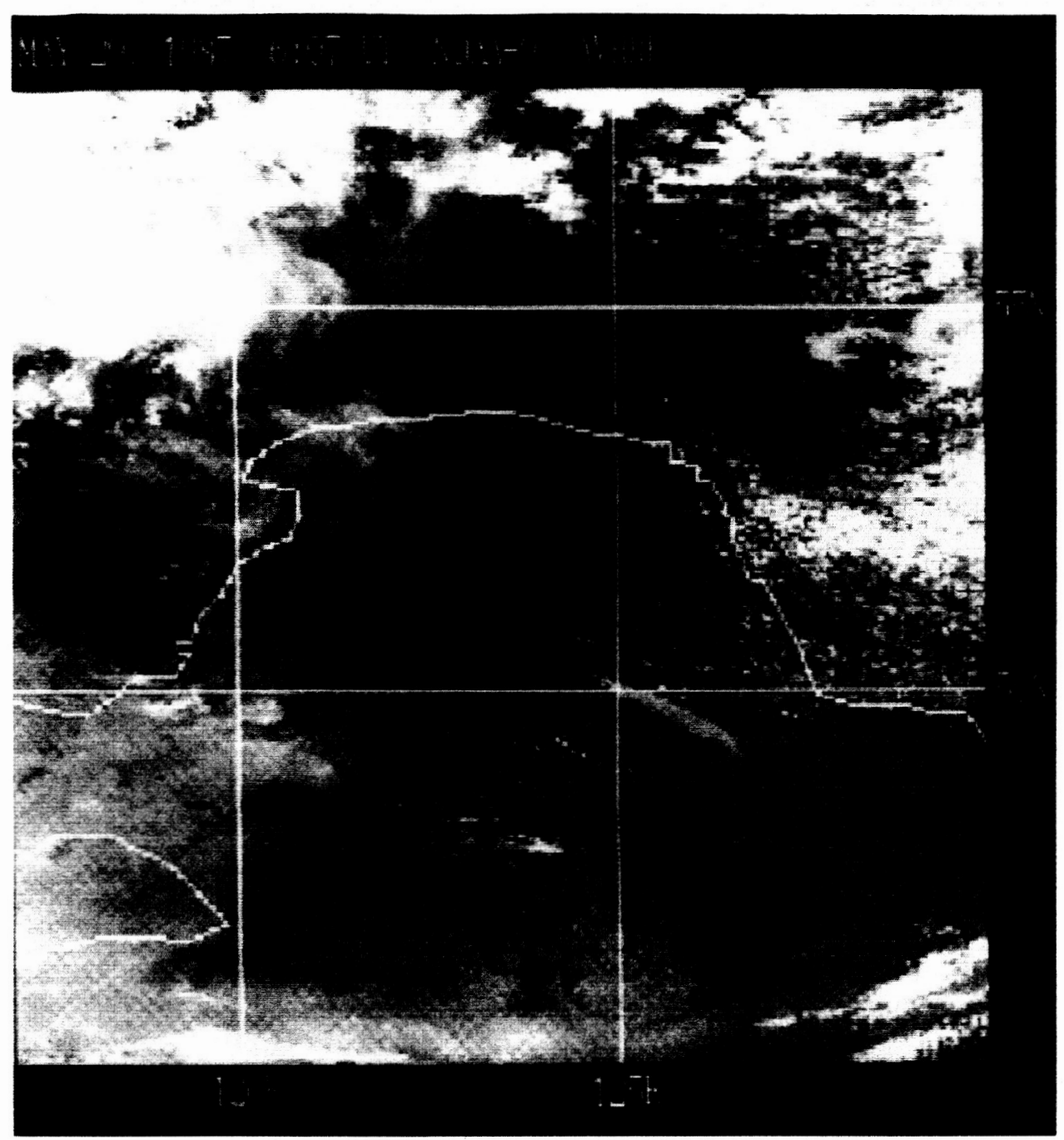

Plate 5. During the last days of May, large fires continued to burn north of the Amur River. The large burn scar in China and the scars from earlier fires in Russia are readily apparent.

of active firest in China on May 16 (Plate 4). The

had burned an area that was now almost continuous, and burned area of the great China fire was clearly visible fewer, less intense, fires were scattered from east of (lighter shade of grey; warmer temperature) within the active fire perimeter (red pixels). The three separate fires in China Lake Baikal to north along the Amur River. At this time, active fires were detected further north in Siberia along the Lena River. These 


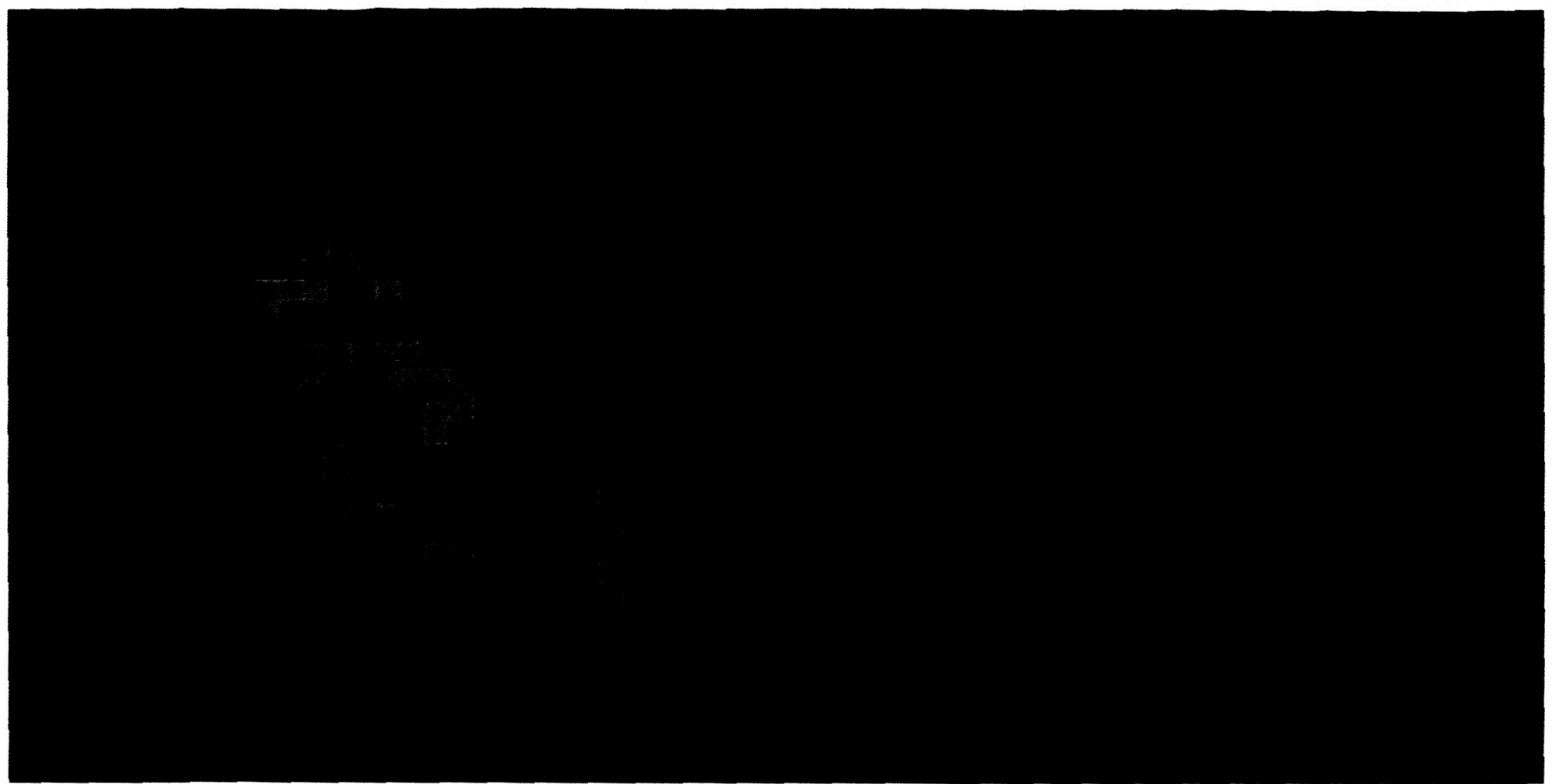

Plate 6. From an AVHRR 4-km image (GAC format) the 1.3 million-hectare burn scar is easily distinuished. Severely burned areas are shown in light blue. This image was acquired on July 29, 1987.

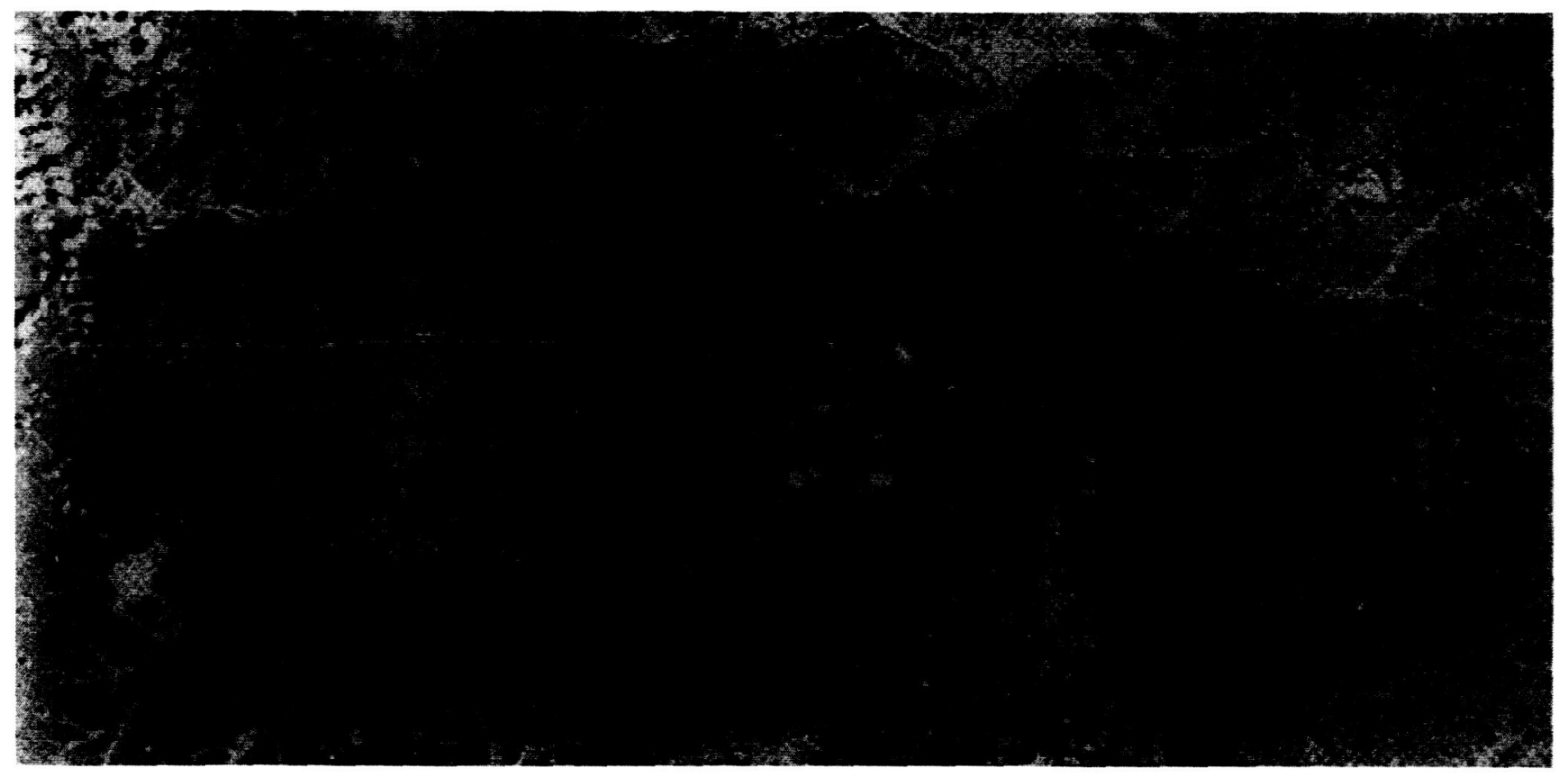

Plate 7. This Landsat TM mosaic is composed of individual scenes from May 23, May 30, and june 6, 1987. The great China fire scar (red) shows the same outline as Plate 6 . The areas of deep red are regions that were severely burned.

fires, seldom visible due to extensive cloud cover, burned over large areas in the vicinity of the Lena River during the late May to early June period.

Toward the end of May, intense burning had occurred, and continued to occur, in a region spanning over $30^{\circ}$ of longitude in southeastern Siberia. Burn scars stretched from http://asd-www.larc.nasa.gov/biomass_burn/sat_anal.html

\section{Burned Area Estimation}

The surface area of burn scars during the 1987 fire episode was estimated from NOAA 9 AVHRR GAC imagery. Even though only the subsampled GAC imagery was available, reasonable area burned estimates can be attained 
east of Lake Baikal to as far as $133^{\circ} \mathrm{E}$ longitude, and fire activity had increased along a line centered at $53^{\circ} \mathrm{N}$ latitude and between $110^{\circ}$ and $125^{\circ} \mathrm{E}$ longitude. On May 27, fire activity increased again to the east of Lake Baikal and also appeared about $450 \mathrm{~km}$ west of northern Lake Baikal. Active fires remained scattered across southeastern Siberia through the end of May. In China, fire activity was greatly diminished (Plate 5), but a few fires continued into June. During the first week in June, the AVHRR imagery revealed very few fires throughout Siberia and China. However, by June 8, a few fires were again widely scattered east of Lake Baikal.

\section{Burn Scar Delineation}

The strong contrast between burned and unburned boreal forest is readily visible in the false-colored AVHRR imagery, making it possible to detect and measure lire scars. Plate 6 shows the great China fire as delineated by AVHRR GAC imagery. A mosaicked, higher-resolution Landsat thematic mapper (TM) scene, courtesy of Chinese fire researchers, is presented in Plate 7 for comparison. The general outline of the burn scar compares very well, and there is also good agreement between the most intensively burned areas in each satellite image. As a further comparison an AVHRR LAC image (Plate 8) acquired in 1990 demonstrates that the intensely burned areas can still be delineated from moderately burned areas many years after a fire. In this image, areas burned by intensive crown fires which destroyed the forest canopy during the major runs of the great China fire are visible as lighter patches. from imagery in the uncorrected orbital projection (Cahoon et al., 1992]. This is particularly true in the boreal forest since the overwhelming majority of burned area is a result of large fires which are easily detected. Because of the intermittent availability of clear sky imagery, which negates the possibility of observing the entire study region at one time, a clear sky mosaic was created (Plate 9). From this mosaic, all burn scars can be observed in a single image, making the area burned estimate simpler and alleviating the concerns of double counting or missing any burned area.

The development of the clear sky mosaic is a several-step process which will be described with the use of matrix notation. For this description, an individual multispectral (threebanded) AVHRR scene is represented by matrix $\mathrm{D}^{n}$, and the mosaic of all the individual AVHRR scenes is matrix $M$, where

$$
D^{2}=\left[\begin{array}{cccc}
d_{11} & d_{12} & \cdots & d_{1 j} \\
d_{21} & d_{22} & \cdots & d_{2 j} \\
\cdot & \cdot & \cdots & \cdot \\
d_{i 1} & d_{22} & \cdots & d_{i j}
\end{array}\right] M=\left[\begin{array}{cccc}
m_{11} & m_{12} & \cdots & m_{1 j} \\
m_{21} & m_{22} & \cdots & m_{2 j} \\
\cdot & \cdot & \cdots & \cdot \\
m_{11} & m_{i 2} & \cdots & m_{u j}
\end{array}\right]
$$

$n$ is the total number of AVHRR scenes; and $i$ and $j$ define the number of elements, $d$ and $m$, in the matrices. Each pixel in the AVHRR image is corrected for brightness changes due to the solar zenith angle. Using the NOAA-supplied navigation data, each element $d_{i j}$ is the result of resampling the 


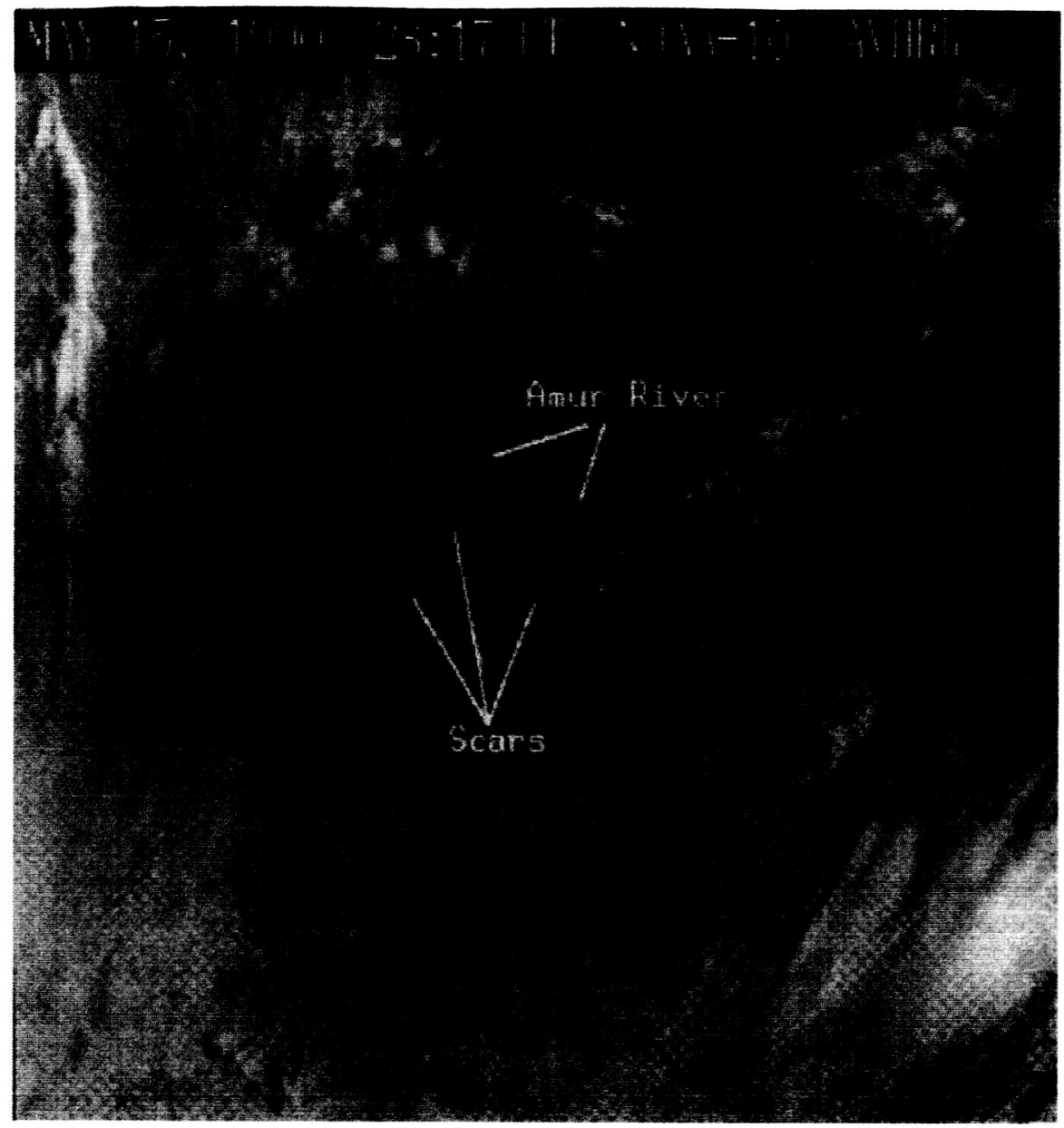

Plate 8. This AVHRR LAC scene from 1990 still shows the most severely burned areas in the great China fire.

original NOAA scene into the cylindrical-equidistant map project. Since each AVHRR scene is resampled, for every $\mathrm{D}^{n}$ the elements $\mathrm{d}_{i j}$ represent the same geographical region and are a function of latitude ( $p h i$ ) and longitude (lambda). The mosaic image $(\mathrm{M})$ is the same size and spatially represents the same geographical area as the AVHRR scenes $\mathrm{D}^{n}$. Then each element of both $\mathrm{M}$ and $\mathrm{D}^{n}$ can be compared, with the results of the comparison composited into a final scene $\left(\mathrm{M}^{\prime}\right)$. The comparison,

$$
\boldsymbol{M}_{i j}^{\prime}=\operatorname{Min}\left(\boldsymbol{D}_{i j}^{n}, \boldsymbol{M}_{i j}\right)
$$

tests for the minimum between the mosaicked image (M) and the AVHRR scene $\left(\mathrm{D}^{n}\right)$ in the AVHRR channel 2 band and saves the elements for all channels of the minimum- 


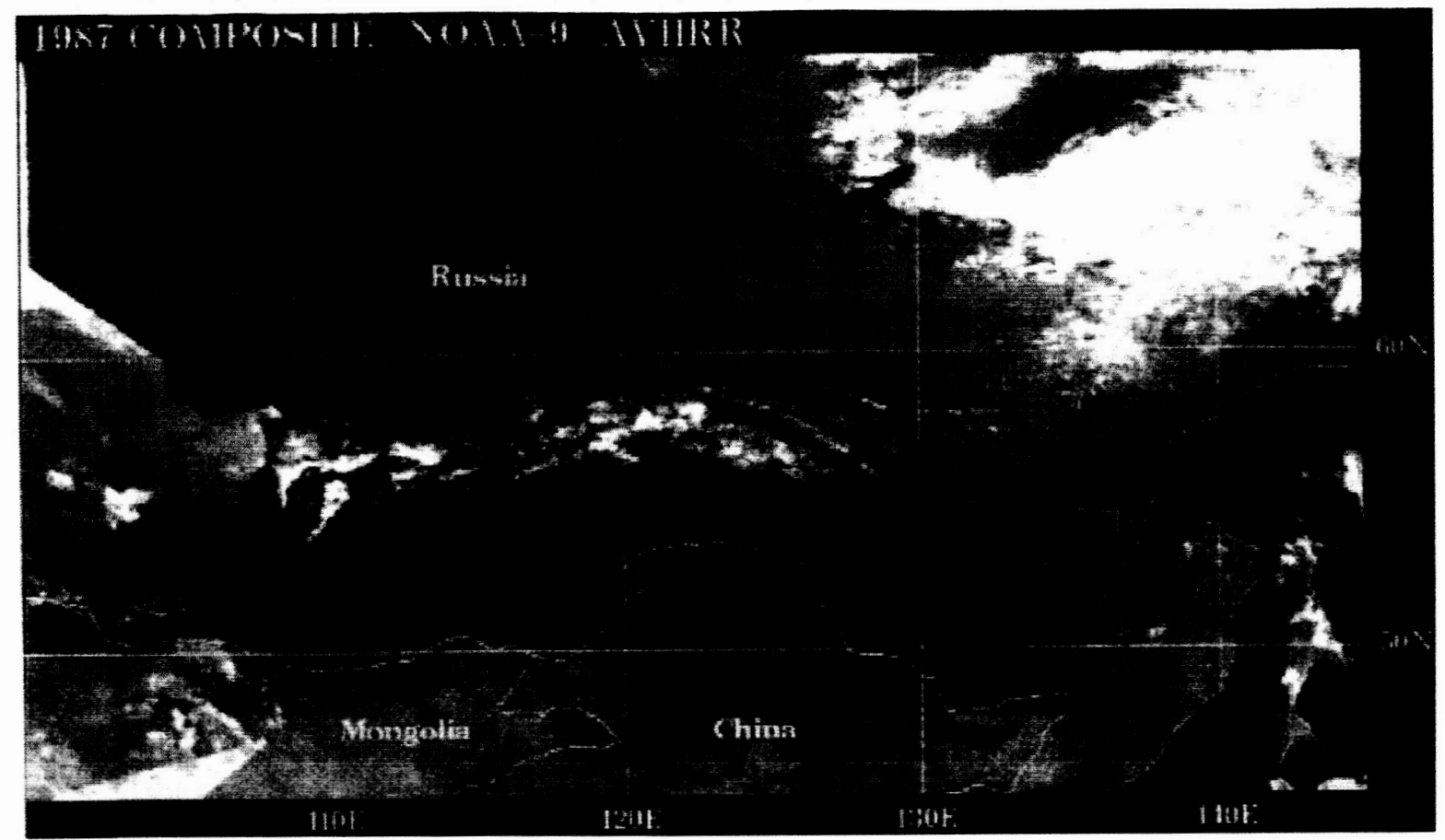

Plate 9. AVHRR clear sky mosaic for the 1987 season.

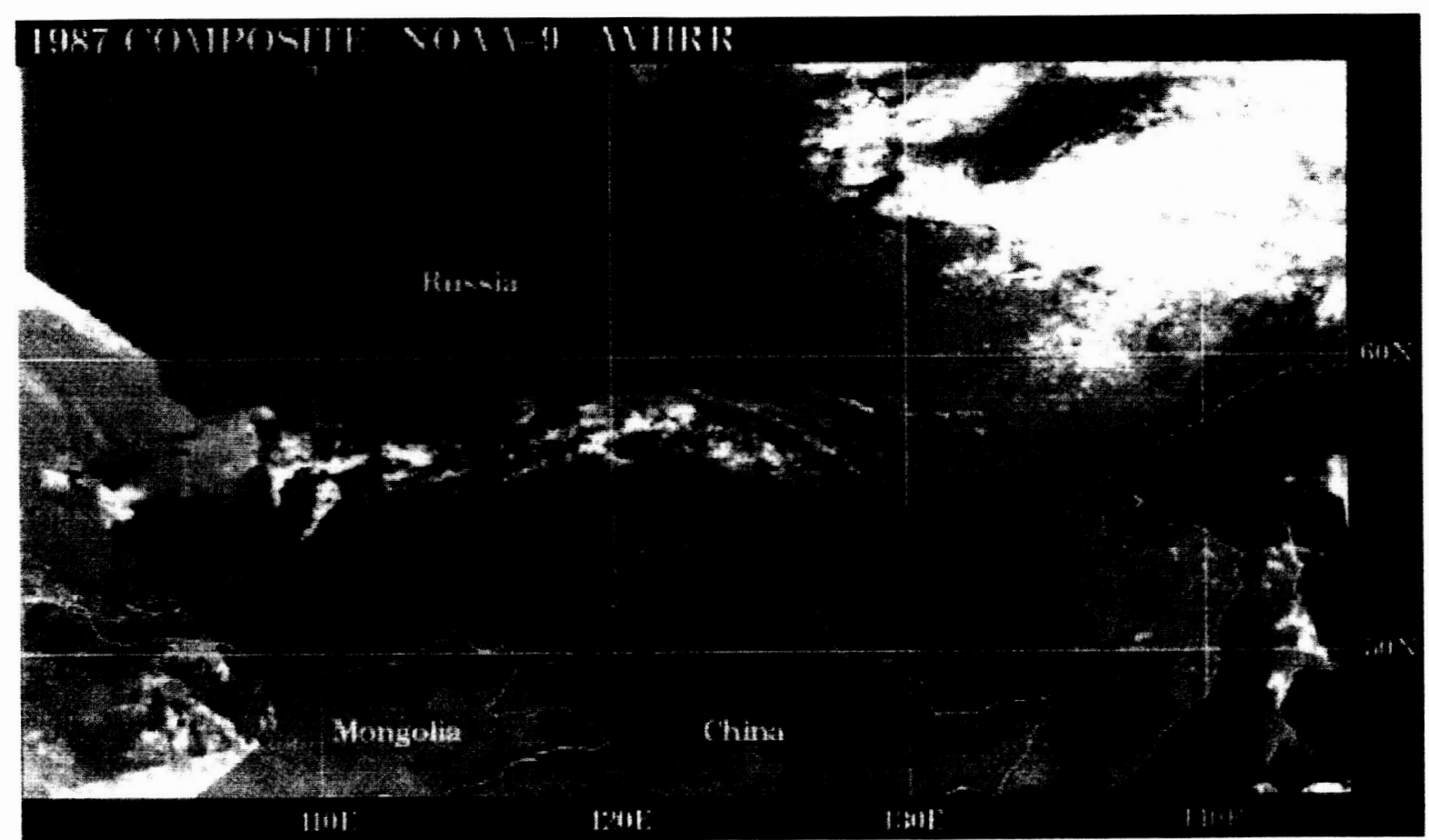

Plate 10. Classified AVHRR clear sky mosaic showing enhanced burn scars (black).

valued image in the new mosaic $\mathbf{M}^{\prime}$. The testing is iterative, pixels that are counted as having a burn scar. The where $\mathbf{M}^{\prime}$ is substituted for $\mathrm{M}$, and continues $n$ times through iterative process continues until burn scars, all of the scenes. Since clouds are highly reflective and the burned area is of low reflectance in the AVHRR channel 2, the burned areas are retained while the clouds are removed. which have been correlated with known fire activity determined from the AVHRR imagery, are isolated and falsely classified pixels have been minimized. The resulting 1987 clear sky 
In estimating the total regional burned area, it was first necessary to classify which image pixels contained burned area. An unsupervised minimum distance classification on AVHRR channels 1,2, and 4 was then used iteratively to isolate the scar pixels and statistically determine the edge mosaic, with the scar pixels blackened to enhance contrast, is shown in Plate 10.

The resulting scar map was subjected to another processing step to determine the area of each pixel. Since a cylindrical-equidistant projection was used and each side of a pixel is parallel to both meridians and parallels, the

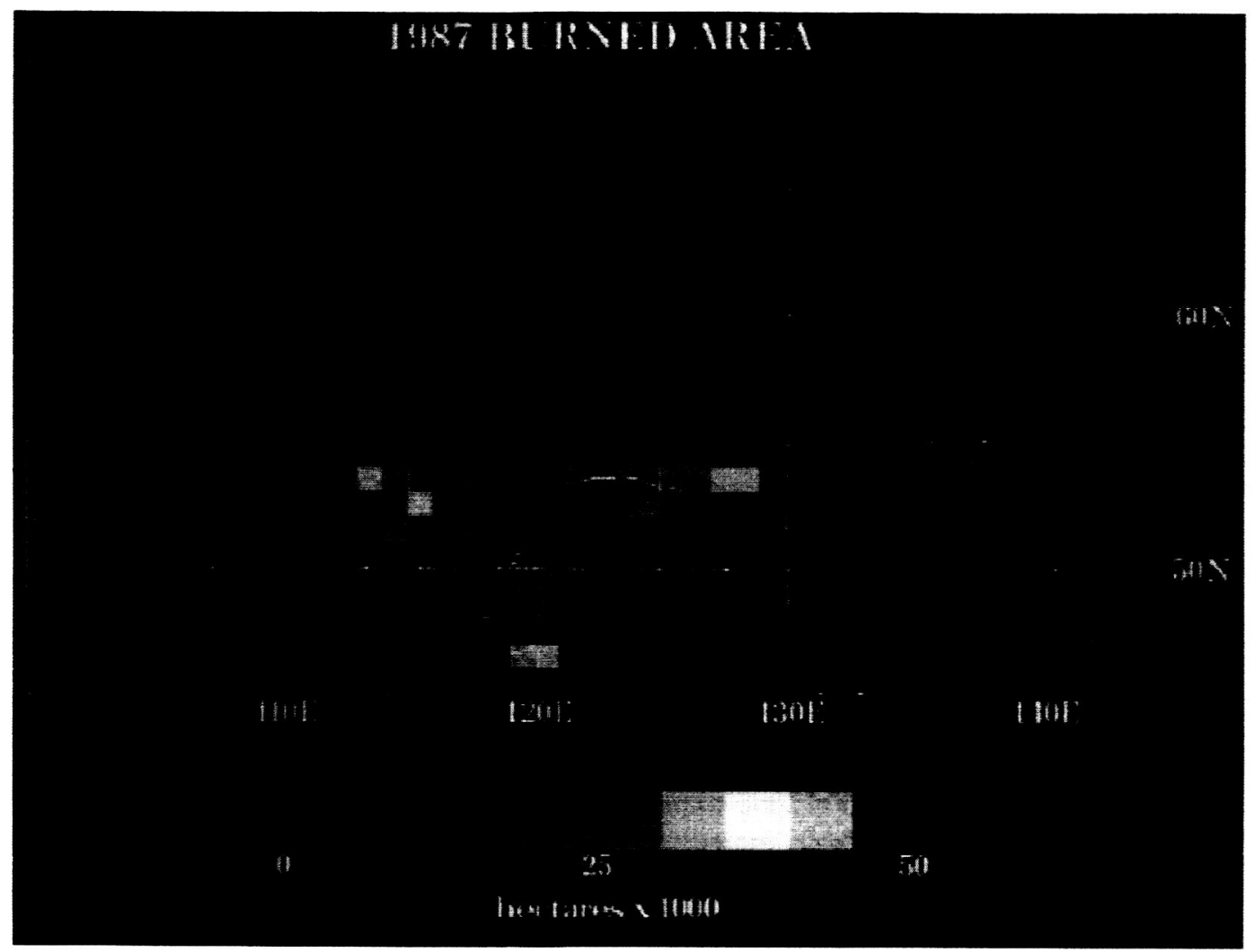

Plate 11. Burned area totals for a $1^{\circ}$ grid over the entire study region.

Table 1. Mean Emission Ratios for Two Combustion Stages in the Boreal Forest

\begin{tabular}{lrcc}
\hline & \multicolumn{3}{c}{ Mean Emission Ratio, \% } \\
\cline { 2 - 4 } $\begin{array}{c}\text { Combustion } \\
\text { Stage }\end{array}$ & $\mathrm{CO}$ & $\mathrm{CH}_{4}$ & NMHC \\
\hline Flaming & 6.60 & 0.61 & 0.60 \\
Smoldering & 12.30 & 1.26 & 0.12 \\
\hline
\end{tabular}

The remaining $C$ is released in particulate form.

distance along each pixel in terms of degrees of latitude and longitude is easy to determine. The distance along a parallel $\left(\mathrm{d}_{\text {phi }}\right)$ is derived using the relationship
Table 2. Mass of Each Gas Released Duri Combustion Stages in the Boreal Forest

\begin{tabular}{lccc}
\hline \multirow{2}{*}{$\begin{array}{l}\text { Sombustion } \\
\text { Stage }\end{array}$} & \multicolumn{3}{c}{ Mass Released by Combust } \\
\cline { 2 - 4 } & $\mathrm{CO}_{2}$ & $\mathrm{CO}$ & $\mathrm{CH}_{4}$ \\
\hline Flaming & 1.877 & 0.124 & $1.145 \times 10^{-2}$ \\
Smoldering & 1.733 & 0.213 & $2.183 \times 10^{-2}$ \\
\hline
\end{tabular}

the fractional time spent in the flaming/smolde important to note that if $80 \%$ of the $\mathrm{C}$ is consul stage, the emissions vary by $2 \%, 18 \%$, and $21 \%$ and $\mathrm{CH}_{4}$, respectively. Therefore the total mas 


$$
d_{+}=\frac{A \Delta \lambda \cos \phi}{\left(1-d^{2} \sin ^{2} \phi\right)^{12}}
$$

where delta-lambda is the change in longitude, $a$ is the Earth's radius at the equator, and $p h i$ is the latitude. The distance along the meridian $\left(d_{\text {lambda }}\right)$ is then

$$
d_{1}=\int_{\phi 1}^{\infty} \frac{a\left(1-e^{2}\right)}{\left(1-e^{2} \sin \phi^{2}\right)^{3 / 2}} d \phi
$$

The area of any pixel $\left(A_{p}\right)$ in the image is then

$$
A_{\nabla}=d_{*} \times d_{1}
$$

The area of every pixel classified as a scar was then summed to derive the total area burned. The error of the area estimates has been tested using the same methods described by Cahoon et al. [1992]. The estimated error is expected to be $\sqsupset \%$. From this image the total burned area was determined to be 14.446 million hectares (35.697 million acres). The area was also totaled for each $1^{\circ} \times 1^{\circ}$ box within the study region (Plate II).

\section{Trace Gas Emission Estimates}

Based on the satellite assessment of burned area, the trace gas emissions for carbon dioxide $\left(\mathrm{CO}_{2}\right)$, carbon monoxide $(\mathrm{CO})$, methane $\left(\mathrm{CH}_{4}\right)$, and nonmethane hydrocarbons (NMHC) were estimated. The accurate estimation of emissions requires a knowledge of the amount of forest fuel consumed during burning. Canadian forest fire research scientists have conducted numerous experimental burning programs in the boreal zone [Stocks, 1987, 1989; Alexander et al., 1991] and have determined fuel consumption figures for boreal fires. Based on the results of these research programs, the average fuel consumption (ground, surface, and aerial fuels) is $2.5 \mathrm{~kg} \mathrm{~m}^{-2}$ $\left(25,000 \mathrm{~kg} \mathrm{ha}^{-1}\right)$. Since dry fuels contain about $45 \%$ carbon (C) by weight [Crutzen and Andreae, 1990], the mass of $\mathrm{C}$ consumed is $1.125 \mathrm{~kg} \mathrm{C} \mathrm{m}^{-2}\left(11,25 \mathrm{OkgC} \mathrm{ha}^{-1}\right)$.

To compute the emissions, the fires are divided into two stages, flaming and smoldering. Both stages produce different levels of emissions in the boreal forest, which affects the final trace gas emission estimates. The amount of time spent in each stage varies widely with fuel type/mixture, moisture content, and weather conditions. For this analysis it was assumed that on average, about $50 \%$ of the $C$ consumed occurs in each of the flaming and smoldering stages of the fire. (There are few data on during combustion for either combustion stage 2 (5630 kg C ha-1). To relate the mass of carbor mass of $\mathrm{CO}_{2}$ released, the mass of $\mathrm{C}$ is multipl stoichiometric factor 44/12 (grams of $\mathrm{CO}_{2}$ /grar burning efficiency (Percentage of combusted $\mathrm{C}$ to $\mathrm{CO}_{2}$.) For the flaming and smoldering stages efficiency is about $91 \%$ and $84 \%$, respectively 1990]. The mass of $\mathrm{CO}_{2}$ released in the flaming $\mathrm{kg} \mathrm{CO}_{2} \mathrm{~m}^{-2}\left(18,770 \mathrm{~kg} \mathrm{CO}_{2} \mathrm{ha}^{-1}\right)$. The mass of the smoldering stage is $1.733 \mathrm{~kg} \mathrm{CO}_{2} \mathrm{~m}^{-2}(17,3$

The other trace gas emissions were estimated $\mathrm{v}$ normalized emission ratios determined from fiı [Cofer et al., 1990]. For both the flaming and s the $\mathrm{CO}_{2}$-normalized emission ratios for $\mathrm{CO}, \mathrm{CH}$

are given in Table 1 . The mass of any trace gas combustion can be obtained by multiplying the combusted $\mathrm{C}$ by the appropriate emission ratio molecular weight ratio of the gas to $\mathrm{C}$. For the average $\mathrm{CO}_{2}$ - normalized emission ratios for $\mathrm{e} \varepsilon$ stage are given in Table 2 . Finally, the emissio burned region were obtained by multiplying th burned by the combustion-released mass per u1 gas. For the 1987 fires in eastern Siberia and n total mass released for each gas is listed in Tab

The computed gaseous emissions from the 198 expressed in terms of grams of $\mathrm{C}$ per element $\mathrm{c}$ compared (Table 4) to the African savanna em [Lacaux et al., 1993] and to the global emissio burning [Andreae, 1991]. The African savanna included for comparison since that ecosystem $\mathrm{t}$ most widespread burning [Andreae, 1991; Lac, As a result of a more incomplete combustion in

\begin{tabular}{|c|c|c|c|}
\hline \multirow{2}{*}{$\begin{array}{l}\text { Combustion } \\
\text { Stape }\end{array}$} & \multicolumn{3}{|c|}{ Total Emission Relesse From } \\
\hline & $\mathrm{CO}_{2}$ & $\mathrm{Co}$ & $\mathbf{C H}$ \\
\hline $\begin{array}{l}\text { Faming } \\
\text { Smoldering } \\
\text { Total }\end{array}$ & $\begin{array}{l}2.71 \times 10^{11} \\
2.50 \times 10^{11} \\
5.21 \times 10^{11}\end{array}$ & $\begin{array}{l}1.25 \times 10^{10} \\
2.33 \times 10^{10} \\
3.58 \times 10^{10}\end{array}$ & $\begin{array}{l}6.61 \times \\
1.37 \times \\
2.03 \times\end{array}$ \\
\hline
\end{tabular}
interesting to note that the 1987 east Asian fire much less $\mathrm{CO}_{2}$ than $\mathrm{CO}$ and 
Table 4. Emission Comparisons

\begin{tabular}{|c|c|c|c|}
\hline & $\mathrm{CO}_{2} \cdot{ }_{B} \mathrm{C}$ & $\mathrm{CO}, \mathrm{s} \mathrm{C}$ & $\mathrm{CH}_{4}, \mathrm{~g} \mathrm{C}$ \\
\hline $\begin{array}{l}1987 \text { east Asian firts } \\
\text { Savanna fire emissions, yr }{ }^{-1} \\
\text { Global biomass burning emissions, yr } \\
\text { Ratio of } 1987 \text { east Asian fire emissions } \\
\text { to savang fre emissions, } \%\end{array}$ & $\begin{array}{l}1.42 \times 10^{14} \\
7.00 \times 10^{14} \\
3.50 \times 10^{15} \\
20\end{array}$ & $\begin{array}{l}1.54 \times 10^{13} \\
4.25 \times 10^{13} \\
3.50 \times 10^{14} \\
36\end{array}$ & $\begin{array}{r}1.52 \times 10^{12} \\
2.20 \times 10^{12} \\
3.80 \times 10^{13} \\
69\end{array}$ \\
\hline $\begin{array}{l}\text { Contribution of } 1987 \text { east Asian fire } \\
\text { emissions to dobal enissions. \% }\end{array}$ & 4 & 4 & 4 \\
\hline
\end{tabular}

$\mathrm{CH}_{4}$ relative to savanna fires which have a more complete combustion. Conclusion

Fire is the dominant force that shapes the development and composition of boreal forests which cover over I billion hectares worldwide, two thirds of which are in Russia. Earlier estimates by Crutzen et al. [1979] and Seiler and Crutzen [1980] suggested that as much as 1.5 million hectares of boreal forest burn annually, but more recent estimates by Stocks [1991] and Kasischke et al. [1993] reported that an average 8 million hectares burned annually during the $1980 \mathrm{~s}$, with great year-to-year fluctuations. The discrepancy in estimates can be partially attributed to a greater awareness during the last decade of fire and its importance in boreal forests, but also reflects the fact that little was known about fire activity in the Russian boreal forests until recently. In 1987, approximately 14 million hectares burned in eastern Asia alone, and even though 1987 may have been an extreme year, the fact remains that an assessment of the spatial and temporal variations of boreal forest fires throughout the world has not been made. This type of assessment is required to determine the cause-and-effect relationship between boreal fires and global change.

The emissions from the 1987 eastern Asia boreal fires have been shown to be significant on the global scale. These emissions may also influence the measurements of other satellite instruments. Fishman et al. [1991] have shown that a tropospheric ozone maximum develops over eastern Asia and extends outward over the North Pacific Ocean during the burning season. Also, the measurement of air pollution from satellite (MAPS) instrument, flown in October 1984, showed a relatively high concentration of $\mathrm{CO}$ over eastern Asia and the North Pacific Ocean [Reichie et al., 1990]. The CO may be at least partially attributed to the emissions produced during the boreal forest burning season. The detectability of these emissions with spaceborne instruments attests to the magnitude of the burning. Boreal forest fires will no doubt impact measurements of the Earth Observing System (EOS) instruments later in this decade. is a $27 \%$ sampling of LAC $(1 \mathrm{~km})$ imagery, Cahoon et al. [1992] have shown that the area burned can be estimated with reasonable error. Hence GAC imagery is appropriate for monitoring fires in the boreal ecosystem. GAC imagery has been archived for over a decade and potentially could provide a long-term record of fires and emissions throughout the boreal forest. With the use of improved emission models, combined with long-term AVHRR-derived burned-area determinations, better estimates of trace gases released to the atmosphere can be made, and a more conclusive understanding of the interactions between the boreal forest and the atmosphere, carbon cycling, and climate change can be attained.

Acknowledgments. The DMSP image (Figure 1) was obtained from Rob Bauer, University of Colorado, National Snow and Ice Data Center. The AVHRR images in Plate 2 and the 1987 Landsat scene in Plate 7 were provided courtesy of Jin Ji-Zhong, formerly with the Heilongiiang Forest Protection Research Institute in Harbin, People's Republic of China. and now with Forestry Canada Ontario Region.

\section{References}

- Alexander. M. F., B. J. Stocks, and B. D. Lawson, Predicting fire behavior in the Black Spruce-Lichen Woodland: The Porter Lake Project, Rep. NOR-X-310, Can. North. Forest Cent., Edmonton, Alta.. Canada, 1991.

- Andreac, M. 0.. Biomass burning: Its history, use. and distribution and its impact on environmental quality and global change, in Global Biomass Burning: Atmospheric, Climatic, and Biospheric Implications. pp.3-21, MTT Press, Cambridge, Mass., 1991.

- Cahoon, D. R., Jr., J. S. Levine, W. R. Cofer III, P. Minnis, J. E. Miller, G. M. Tennille, T. 
Because of the significant amount of emissions, it is important W. Yip, P. W. Heck, and B. J. Stocks, The to quantify the interannual variations of buming throughout great Chinese fire of 1987: A view from space, the entire boreal forest system and improve emission modeling in Global Biomass Burning: Atmospheric. for this ecosystem. Extreme meteorological conditions, in combination with the lack of accessibility, result in large, high-intensity crown fires throughout the world's boreal forests. Stocks [1991] reported that most of the area is burned by the largest of these fires, and it has been demonstrated that these large fires are clearly discernible in the GAC imagery. Even though GAC $(4 \mathrm{~km})$ imagery Climatic, and Biospheric Implications, pp. 6166, MIT Press, Cambridge, Mass., 1991. - Cahoon, D. R., Jr., B. J. Stocks, J. S. Levine, W. R. Cofer III, and C. C. Chung, Evaluation of a technique for satellite-derived estimation of biomass burning, J. Geophys. Res., 97(D4), 3805-3814, 1992.

- Chung, Y. S., and H. V. Le, Detection of forest-fire smoke plumes by satellite imagery, Atmos. Environ., 18, 2143-2151, 1984. - Cofer, W. R., III, J. S. Levine, F. L. Winstead, and B. J. Stocks, Gaseous emissions from Canadian boreal forest fires, Atmos.

Environ., Part A, 24,1653-1659,1990.

- Crutzen, P. J.. and M. 0. Andreae, Biomass burning in the tropics: Impact on atmospheric chemistry and biogeochemical cycles, Science, 250, 1669-1678, 1990.

- Crutzen, P. J., L. F. Heidt, J. P. Krasnec, W. H. Pollock, and W. Seiler, Biomass burning as a source of atmospheric gases $\mathrm{CO}, \mathrm{H}_{2}, \mathrm{~N}_{2} \mathrm{O}$, $\mathrm{CH}_{3} \mathrm{Cl}$, and COS, Nature, 282, 253-256, 1979.

- Fishman, J., K. Fakhruzzaman, B. Cros, and D. Nganga, Identification of widespread pollution in the southern hemisphere deduced from satellite analysis, Science, 252, 16931696. 1991.

- Kasischke, E. S., N. H. F. French, P. Harrell, N. L. Christensen Jr., S. L. Ustin, and D. Barry, Monitoring of wildfires in boreal

forests using large area AVHRR NDVI composite image data, Remote Sens. Environ., 44, 1-10, 1993.

- Kidwell, K. B., NOAA Polar Orbiter Data (TIROS- - Stocks, B. J., The extent and impact of forest fires in N, NOAA 6, NOAA 7, NOAA 8, NOAA 9, NOAA 10, NOAA 11) Users Guide, National Environmental Satellite Data and Information Service, Washington, D. C., 1991.

- Lacaux, J. P., H. Cachier, and R. Delmas, Biomass burning in Africa: An overview of its impact on atmospheric chemistry, in Fire in the Environment: The Ecological, Atmospheric, and Climatic Importance of Vegetation Fires, pp. 15 191, John Wiley, New York, 1993.

- Matson, M., and I. Dozier, Identification of subresolution high temperature sources using a thermal IR sensor, Photogramm. Eng. Remote Sens., 47(9), 1311-1318,1981.

- Reichie, H. G., Jr., V. S. Connors, J. A. Holland, R.

T. Sherrill, H. A. Wallio, J. C. Casas, E. P. Condon,
- Stocks, B. J., Fire behavior in mature jack pine, Can. J. For. Res., 19, 783-790, 1989. northern circumpolar countries, in Global Biomass Burning: Atmospheric, Climatic, and Biospheric Implications, pp.197-202, MIT Press, Cambridge, Mass., 1991.

- Stocks, B. J., and J. Z. Jin, The great China fire of 1987: Extremes in fire weather and fire behavior, paper presented at the 1988 Annual Meeting, Fire Management in a Climate of Change, Northwest Fire Council, Victoria, B. C., Canada, Nov. 1 15, 1988.

- Warren, S. G., C. J. Hahn, J. London, R. M. Chervin, and R. L. Jenne, Global distribution of total cloud cover and cloud type amounts over land, $N C A R / N-273+S T R$, Natl. Cent. for Atmos. Res., Boulder, Cob., 1986.

D. R. Cahoon Jr., W. R. Cofer III, J. S. Levine, and J. M. Pierson, 
B. B. Gormsen, and W. Seiler, The distribution of middle tropospheric carbon monoxide during early October 1984, J. Geophys. Res., 95(D7), 9845-9856, 1990.

- Scorer, R. S., Hot spots and plumes: Observation by meteorological satellite, Atmos. Environ., 21, 1427-1435,1987.

- Seiler, W., and P. J. Crutzen, Estimates of gross and net fluxes of carbon between the biosphere and the atmosphere from biomass burning, Clim. Change, 2, 407-247, 1980.

- Stocks, B. J., Fire behavior in immature jack pine, Can. J. For. Res., 17, 80 86, 1987.
Atmospheric Sciences Division, NASA Langley Research Center, Mail Code 423, Hampton, VA 23681-0001. (e-mail:

d.r.cahoon@larc.nasa.gov; j.s.levine@larc.nasa.gov.)

B. J. Stocks, Canadian Forest Service, 1219 Queens Street East, Sault Ste. Marie, Ontario, Canada P6A 5M7. (e-mail: stacks@fcor.glf.forestry.ca)

(Received July 23, 1993; revised April 1, 1994; accepted April 14, 1994.)

Last Updated: 10/01/2002 12:44:34

Web Curator: P. Kay Costulis (p.k.costulis@larc.nasa.gov)

Responsible NASA Official: Dr. Joel S. Levine, Atmospheric Sciences Competency

Feedback on Langley Products and Services 